for graduate work at Yale. This was interrupted by field work in Mexico and Venezuela for the Gulf Oil Company. He returned to Yale for further graduate studies in 1928-1930, when he resumed his appointment with the Geological Survey. His doctorate was received in absentia in 1936.

Bramlette soon entered into a close and remarkably fruitful association with that outstanding specialist in Mollusca, Wendell P. Woodring, for a series of brilliant stratigraphic studies in California: the Palos Verdes Hills, Kettleman Hills and Santa Maria Valley. It was then that Bramlette began his petrological studies of the sedimentary rocks, dealing especially with intrastratal alterations, phosphates, zeolites and siliceous cements, culminating in his classic paper on the cherts of the Monterey Formation. He also began his studies of Cenozoic micropalaeontology and with his keen discernment was soon able to identify many of the diagnostic foraminifera in the field with a hand lens.

Bramlette was a principal investigator, along with W. H. Bradley and K. E. Lohman, of the transatlantic series of Piggott cores during the 1930's. With our current plethora of much longer deep sea cores, this work has been nearly forgotten; nevertheless it was the first study of deep-sea stratigraphy and was highly significant in permitting the first correlation of European and American glaciations. At this time he laid the groundwork, through his studies of the Arkansas bauxite deposits, for the great increase in productivity of these mines during the submarine-induced crisis of the second world war.

In 1940 Bramlette joined the faculty of the University of California at Los Angeles, where he remained until his transfer to the Scripps Institution of Oceanography in 1951, except for two years during World War II, when he worked on the bauxite deposits of Arkansas and Jamaica.

At the Scripps Institution Bramlette began his highly rewarding studies of the fossil coccoliths. Because of their minute size and irregular forms, these organisms sink very slowly in the sea so that currents distribute them almost world-wide. Accordingly they constitute unusually valuable time markers for the widespread correlations of marine sediments. Bramlette's contribution to the development of such correlations was pre-eminent, and he continued as a world leader long after his formal retirement in 1964.

Bramlette's versatility and profound scholarship were outstanding. He was elected to the National Academy of Sciences in 1954, was awarded its Thompson Medal in 1964, the Distinguished Service Medal of the Depart- ment of the Interior in 1963, and the Doctor of Laws degree from the University of California in 1965.

He died of emphysema on March 31, 1977. He was a modest gentleman.

James Gilluly

\section{A. L. Walpole}

Dr Arthur Walpole died at Wilmslow, Cheshire on 2 July 1977, aged 64 . Trained initially as a chemist (Imperial College London, B.Sc., Ph.D.), he spent a short period in the Department of Pharmacology, Edinburgh, and then joined the biological section of the new pioneer group in the Dyestuffs Division of ICI Ltd, in Manchester, which ultimately became the Pharmaceuticals Division.

His early interest, on the implication of novel synthetic oestrogens in the treatment of tumours, coupled with the appointment of Professor (later Sir) Alexander Haddow as a consultant, began Walpole's concern with cancer research, for which he is best known. His work fell under two headings. First came his collaboration with Michael Williams, who as Medical Officer for the Dyestuffs Division was deeply involved in its associated industrial hazards. Together over the years, with ad hoc synthesis where needed, they worked out structure/carcinogenic relationships, particularly amongst the arylamines, which still remain of worldwide significance.

Alongside this, and arising in part from the textile interests of the Division, Walpole was amongst the earliest (1947 onwards) to study the effect of introducing alkylating groups such as methylolamido, epoxide and aziridyl into potential tumour-inhibitory structures. His recognition of the peculiar cytotoxic properties induced by these moieties again had implications for industrial safety.

Walpole's other over-riding interest was in the hormonal control of reproduction and related phenomena. Thus researches around basic derivatives of the oestrogenic triphenylethylenes have recently led to a compound especially useful in the treatment of certain forms of mammary carcinoma. Likewise, he pioneered parallel studies in animal husbandry, first using certain disthiodiureas, and later the new synthetic prostaglandins. He was engaged on this latter work at the time of his death, two years after formal retirement.

As a person, he naturally attracted a wide circle of friends and collaborators, and his other qualities extended deeply into the arts. Above all, he was much concerned for humanity, whether in the mass or the individual. $\mathrm{He}$ leaves a widow, Dora.

F. L. Rose

\section{G. G. Villela}

Professor Gilberto G. Villela, the founder of modern biochemistry in Brazil, died on 17 July 1977, aged 73 .

Dr Villela was born in Minas Gerais, Brazil, on 12 July 1904. After graduating in medicine in 1926 he entered the Oswaldo Cruz Institute with which he was associated, first as a student and then as a member of the staff, until the time of his death.

Dr Villela was an authority in the field of biochemistry and he made many significant contributions specially in vitaminology and enzymology. Another field of active interest was the biochromes, where he made many contributions to the study of animal pigments. His publications, more than 300 papers, appeared in medical and biochemical journals in Brazil, Britain, the United States and elsewhere. He was also the author of several scientific books.

Dr Villela visited, lectured and carried out scientific work at many important research centres all over the world, including the University of California Medical School (1945), University College London (1949), the Pasteur Institute (1950), and New York University (1961), where he was a Visiting Professor. As a UNESCO representative he set up a new centre of biological research at the University of Rangoon, Burma (1967). More recently he went to Japan as a lecturer, at the University of Nagoya (1973) and as Chairman of the Xth International Congress of Nutrition in Kyoto (1975).

Dr Villela was elected to several international scientific societies and received several medals and prizes. $\mathrm{He}$ was the founder and first President of the Brazilian Society of Biochemistry, and attended most of the Society's meetings.

Dr Villela's life was fully devoted to his scientific interests which he pursued with enthusiasm and vigour. To his co-workers and students he was an inspiring and ever-helpful teacher. $\mathrm{He}$ enjoyed discussions; his mind was very critical but combined with a good sense of humour. He was a man of high moral standing and humanistic education. He will always be warmly remembered by all who knew him.

He is survived by his widow Regina, one son, Gilberto, one married daughter, Sonia and a grandson, Pedro.

Emilio Mitidieri 